\title{
Oral management of patients with cancer
}

\author{
Manejo oral de pacientes con cáncer
}

\author{
Claudia Patricia Lopez Silva ${ }^{1}$, Mathew Albert Wei Ting ${ }^{2,3}$, Pritam Daniel Sundaresan ${ }^{4}$, Gelsomina Borromeo ${ }^{5,6}$
}

\author{
DCD SND student, Melbourne Dental School, University of Melbourne, Victoria, Australia \\ PhD student, Melbourne Dental School, University of Melbourne, Victoria, Australia \\ Director of Dental Services, The Alfred Hospital, Melbourne, Victoria, Australia \\ Special Needs Dentist, Fiona Stanley Hospital, Perth, Western Australia \\ Associate Professor, and Specialist in Special Needs Dentistry. Eastern Health Clinical School, Monash University, Victoria, Australia \\ Honorary Professor, Special Needs Dentistry, Melbourne Dental School, University of Melbourne, Victoria, Australia
}

\begin{abstract}
The oral management of individuals affected by medical conditions, including those with a current cancer diagnosis, is often complex and as such should be provided by either experienced dentists or dental specialists (e.g. Special Needs Dentists) with adequate training and experience. Patients with cancer need early dental intervention as the cancer itself or its therapy may place them at increased risk of systemic and oral complications.

In Colombia, Special Needs Dentistry (SND) has not been formally recognized as a specialty and does not form part of the current dental curricula suggesting a paucity of suitably qualified dentists to provide complex oral care for oncology patients. While it is accepted that general dentists will provide the bulk of care to these individuals, their knowledge base is unclear. This paper aims to improve the knowledge base around complex SND by addressing the oral complications faced by this patient cohort and how to prioritize treatment, together with proposing a simple protocol to streamline coordination of care between the dental, allied health and medical teams, that is, through a multidisciplinary approach. It is important to acknowledge that dentists have a role at all three levels of the multidisciplinary management of cancer patients: pretreatment evaluation and preparation, oral care during treatment and post-treatment care.
\end{abstract}

Key words: complications, dental care for chronically ill, drug therapy, radiotherapy, patient care team

\begin{abstract}
Resumen
El manejo oral de las personas afectadas por condiciones $\mathrm{m}$ dicas, como el c ncer, a menudo es complejo y como tal debe ser proporcionado por dentistas experimentados o especialistas en reas dentales (por ejemplo, dentistas que atienden necesidades especiales) que cuenten con la formaci $\mathrm{n}$ y la experiencia adecuadas. Los pacientes con c ncer necesitan una intervenci n dental temprana, ya que el c ncer en s o su terapia pueden ponerlos en mayor riesgo de complicaciones sist micas y orales.

En Colombia, la Odontolog a de Necesidades Especiales (ONE) no ha sido reconocida formalmente como una especialidad y no forma parte de los planes de estudios de las escuelas de odontolog a, lo que indica que hay una escasez de dentistas adecuadamente calificados para proporcionar atenci $\mathrm{n}$ oral compleja para pacientes oncol gicos. Si bien se considera que los dentistas generales pueden proporcionar la mayor parte de la atenci $\mathrm{n}$ a estas personas, su base de conocimiento no es clara. Este documento tiene como objetivo mejorar la base de conocimientos en torno a la ONE abordando las complicaciones orales a las que se enfrenta este grupo de pacientes y c mo priorizar el tratamiento, junto con la propuesta de un protocolo simple para agilizar la coordinaci $\mathrm{n}$ de la atenci $\mathrm{n}$ entre los equipos $\mathrm{m}$ dicos, dentales y personal de apoyo, es decir, a trav s de un enfoque multidisciplinario. Es importante anotar que los dentistas cumplen un papel en los tres niveles del manejo multidisciplinario de los pacientes con c ncer: evaluaci $n$ y preparaci $n$ previa al tratamiento, cuidado oral durante el tratamiento y atenci n postratamiento.

Palabras clave: atenci $\mathrm{n}$ dental para enfermos cr nicos, complicaciones, grupo de atenci $\mathrm{n}$ al paciente, quimioterapia, radioterapia
\end{abstract}

Submitted: December 2/2018 - Accepted: March 5/2019

How to quote this article: Lopez-Silva CP, Wei Ting MA, Sundaresan PD, Borromeo G. Oral management of patients with cancer. Rev Fac Odontol Univ Antioq. 2019; 31(1-2): 178-197. DOI: http://dx.doi.org/10.17533/udea.rfo.v31n1-2a16 


\section{INTRODUCTION}

One of the most complicated patient categories in Special Needs Dentistry (SND) centers around cancer management ranging from the illness itself and the management of oral-health related complications. As such, cancer management is often multifaceted involving interventions from a range of disciplines predominately due to the array of complications that can arise as a result of both the illness and its management. Patients with cancer need early dental intervention to avoid the potential risk of systemic and oral complications. ${ }^{1,2}$ Ideally, oral management should be embedded as part of a multidisciplinary team approach including oncologists, nurses, dentists, social workers, dieticians and other health professionals. $^{2-4}$

A recent Colombian study which evaluated the oral status in patients who had received radiotherapy to head and neck found that common oral complications in this population included hyposalivation, trismus and periodontal disease. ${ }^{5}$ This study, which also explored dentists' involvement in the management of these patients, indicated that dental care was the most common unmet health care need for cancer patients. Dentists played little or no role as part of the multidisciplinary team involved in patient care. The barriers identified cantered around health care delivery including the lack of proper referral pathways, inadequate oral health services and inappropriately trained dentists. ${ }^{5}$

Dental specialists, predominately Special Needs Dentists, with additional training and experience are required to manage the oral health of individuals with cancer and indeed those with complex healthcare needs. ${ }^{6,7}$ However, training in SND in Colombia, unlike other specialties, is not offered in tertiary specialist training facilities since it is not recognized as a dental specialty. ${ }^{8}$ Additional training is available in other South American countries such as a postgraduate degree offered by the Universidad de Buenos Aires. ${ }^{9}$ Hence those in Colombia must seek entrance to such training programs there or travel abroad to upgrade their skill base. The main drawback of limited options for additional training results is a workforce inexperienced in managing these individuals, in particular the cancer population. ${ }^{5}$ Regardless of the steps being taken to address this shortage, which will be of benefit in the long term, general dental training needs to be improved to meet the needs of the patients today. ${ }^{5}$ It is not surprising that Colombian general dentists may be unwilling or uncertain about how to engage with multidisciplinary teams or lack a comprehensive understanding of managing cancer patients. ${ }^{710}$ While there has been some useful information about altering oral care, particularly for those with head and neck cancers, an established process for the oral health care management for this population related to our specific clinical setting is lacking. ${ }^{5}$ The purpose of this paper is to provide a protocol for the oral health care management for patients with cancer that attend community-based dental practices in Colombia and other countries that lack access to specialists in special needs dentistry. 


\section{Dental implications for cancer patients and management}

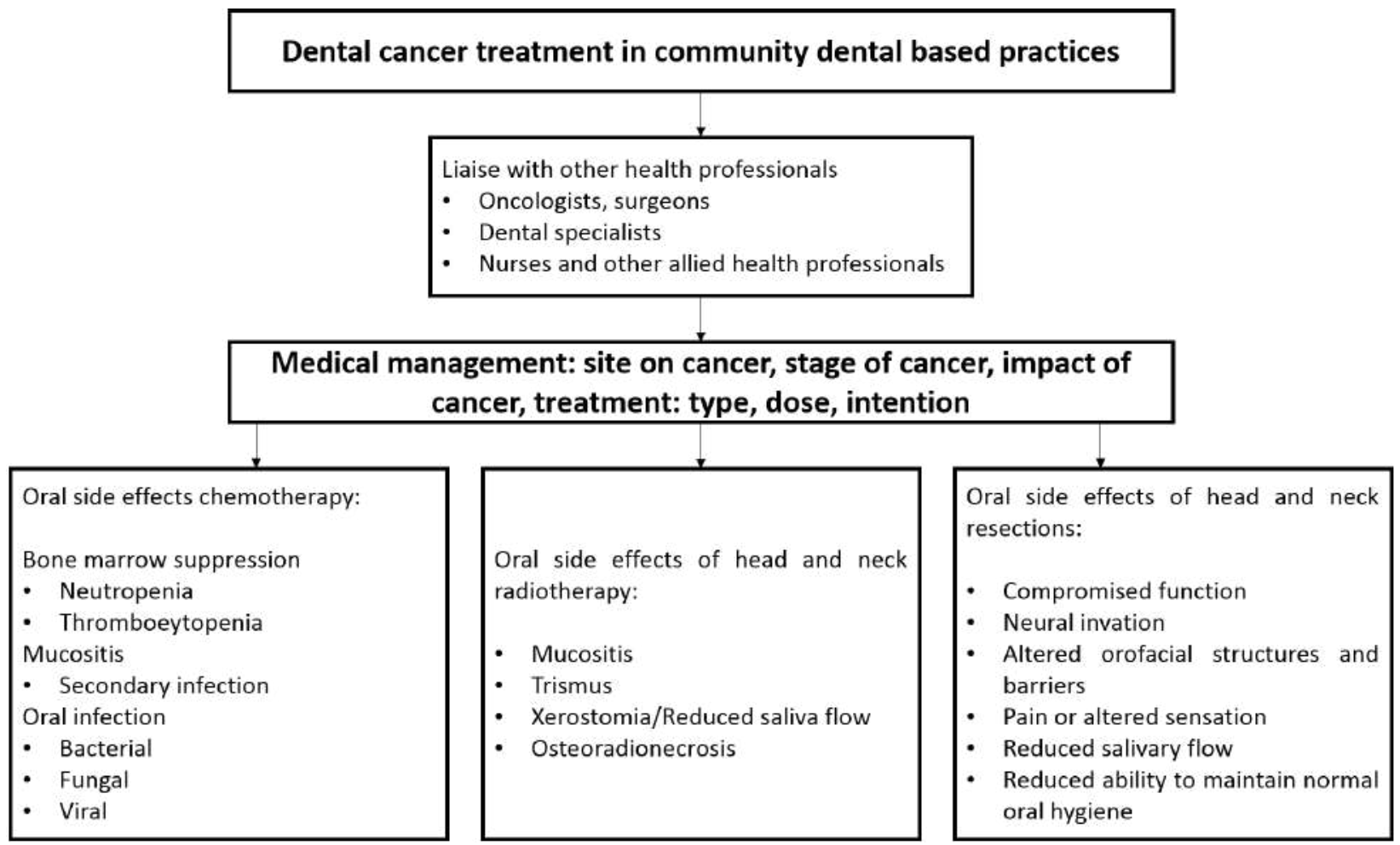

Figure 1. Oral management and risk assessment of patients with cancer

Source: by the authors

Before initiating any dental treatment, a risk assessment should be completed due to potential complications associated with cancer diagnoses and their management (Figure 1). ${ }^{11}$ For example, the medical status of some patients, such as those with leukemia, multiple myeloma and Hodgkin's lymphoma, may interfere with the priority or timing of dental treatment. ${ }^{4,12}$

Intraoral conditions, such as gingival hyperplasia in a patient with leukaemia, may be the first clinical manifestations of cancer which may first present to a general dentist. Dentists should be aware of any suspicious changes in patients' oral health beyond just the teeth. $^{13}$ Thrombocytopenia manifests as petechiae (small dot like reddening of the mucosa) and ecchymosis (bleeding of the oral mucosa). ${ }^{4}$ Likewise, non-healing wounds and oral ulcerations can be the result of granulocytopenia (only detected via a blood test) (Figure 2). ${ }^{12}$ These should prompt the dentist to refer the patient to a general medical practitioner for further management and investigation. 

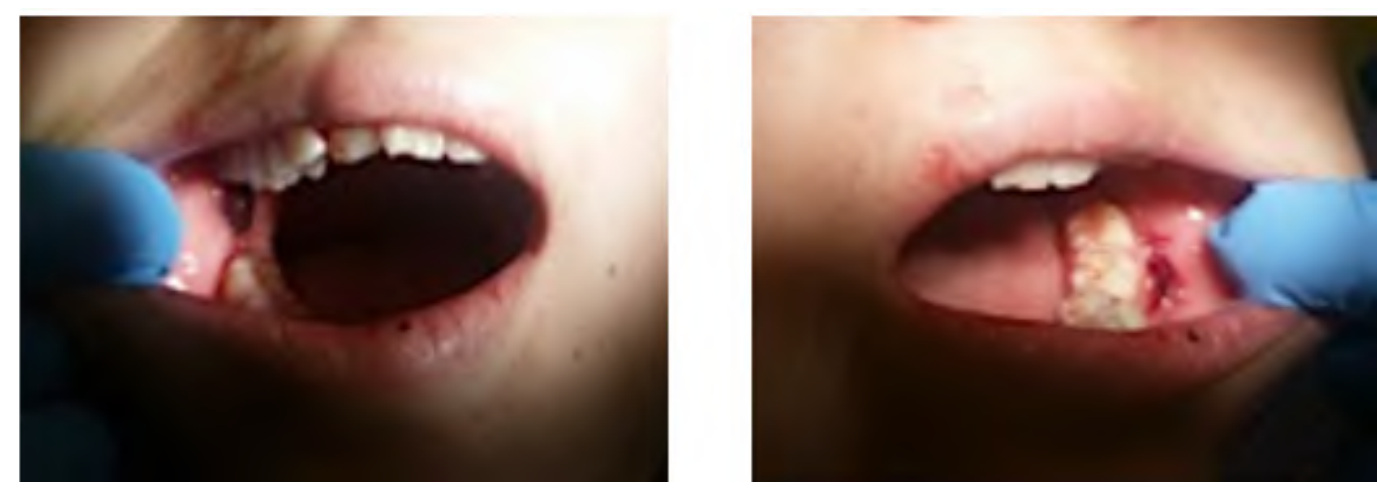

Figure 2. Patient whose first presentation of acute myeloid leukemia was bleeding ulcers.

Source: by the authors

Cancer patients also commonly present with anemia, leukopenia (white cell count $<4400 / \mathrm{uL}$ ) or thrombocytopenia (platelet count $<150,000 / \mathrm{uL}$ ) due to the effects on blood cell production by either the malignancy or cancer therapy (e.g. multiple myeloma and leukemia). ${ }^{12}$ These are important considerations because neutropenia (a decrease in the number of circulating neutrophils below 1000 cells/ $\mu \mathrm{L}$ ) can predispose patients to life threatening complications such as infection including oral infections. ${ }^{12,14}$ In addition, infection can lead to other complications including dehydration and malnutrition, which may necessitate cessation of cancer therapy thereby affecting patient survivorship. ${ }^{15}$

Thrombocytopenia may increase bleeding tendency and impact dental treatment including extractions. Extractions can be performed if the platelet count is above $50,000 /$ uL. It is imperative to follow hemostasis protocols, such as the use of hemostatic agents in the socket and suturing to achieve primary closure. ${ }^{16}$ Furthermore, platelet transfusions are indicated for patients with platelet count below 50,000/uL before extractions or dentoalveolar surgery, and regional blocks avoided with counts below
$30,000 / \mathrm{uL}$ due to the risk of hematoma. ${ }^{12}$ The management of these patients requires close collaboration with the treating medical team and potential hospital admission for dental management if possible.

The organ affected by the primary tumor also requires consideration. For example, liver cancer can decrease the production of clotting factors, leading to an increased bleeding tendency. ${ }^{17}$ Consequently, liver function tests and coagulation profiles, undertaken by referring medical clinicians or if possible the patient's medical practitioner should be considered before undertaking any invasive dental treatment. ${ }^{16}$

Cancer pain is also commonly reported and could be the result of direct tumor involvement (such as impingement on nerves and invasion of tumor into skin, muscles and bone), cancer-induced syndrome (e.g. peripheral neuropathy) or a consequence of diagnostic and therapeutic procedures such as chemotherapy, radiotherapy or surgery. ${ }^{18,19}$ Pain arising from mucositis can interfere with oral intake leading to adverse outcomes such as weight loss and dehydration..$^{20,21}$ Dentists, in consultation with the treating physician, should evaluate 
and treat cancer pain when it has the potential to compromise the oral cavity. ${ }^{22}$

Other symptoms associated with chemotherapy or radiotherapy include nausea, vomiting and fatigue which also impact on oral health and quality of life. ${ }^{23-}$ 25 These individuals may neglect oral care resulting in an increased risk of infection not to mention deleterious changes to the oral structures. ${ }^{26}$ This, coupled with issues around neutropenia, can cause serious medical complications such as sepsis. ${ }^{27}$ Vomiting can also alter oral $\mathrm{pH}$ predisposing to erosion and subsequent oral pain or caries risk. ${ }^{27-29}$

Cardiac disorders can also be complicated by cancer therapy. ${ }^{30}$ Two important considerations when providing dental treatment should be to eliminate pain and minimize anxiety. ${ }^{31}$ Appointments should be scheduled in the morning when the patient is well rested. Adequate pain control should be offered during treatment and postoperatively. Procedure time should also be kept to a minimum to reduce stress and fatigue, restlessness, sweating, and discomfort. $^{31,32}$

Metastatic bone disease has significant dental implications with respect to antiresorptive medications such as bisphosphonates and Denosumab. ${ }^{33}$ These agents, coupled with other factors such as poor oral health, dental extractions, age, smoking, and poorly fitting oral appliances, place patients at a higher risk of developing medication-related osteonecrosis of the jaw (MRONJ). ${ }^{34}$ Pain, eating discomfort, self-consciousness, poor diet, interrupted meals, irritability, and decreased life satisfaction can ensue, each with potential oral health implications. Infection and jaw fracture can also result if these lesions are not addressed. Therefore, implementing a prophylactic dental assessment and necessary dental interventions prior to these therapies is necessary to reduce $M R O N J$ risk especially given it is often recalcitrant to treatment and management may involve surgical intervention, antimicrobial mouthwashes and antibiotic therapy. ${ }^{35}$

\section{Oral complications of chemotherapy and radiotherapy}

Acute side effects

\section{Oral mucositis}

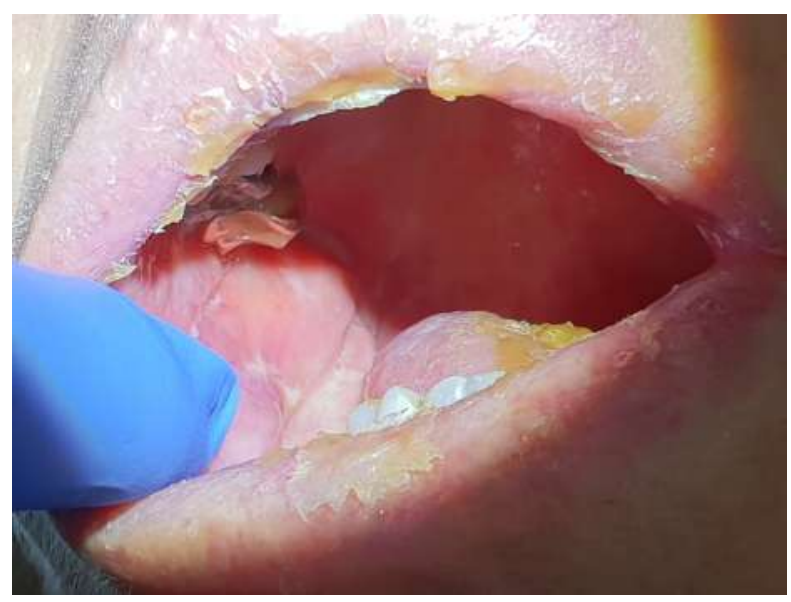

Figure 3. Intraoral imagen showing oral mucositis grade 4 Source: by the authors

Mucositis may develop as a result of disruptive toxicity from chemotherapy and/or radiotherapy (Figure 3). ${ }^{36-38}$ There are differences in the cellular events of chemotherapy and radiation-induced mucositis. Mucotoxic chemotherapy may be delivered over just a single brief period or spread out over no more than a few days (e.g. haematopoietic stem cell transplant). ${ }^{39}$ The symptoms are acute with ulcerations developing typically within one week after initiation of chemotherapy and reaching a peak within 2 weeks. ${ }^{40}$ Ulcerations may develop in the mouth as well as in mucous 
membranes lining the digestive tract. $^{39}$ In oral mucositis, lesions are usually limited to non-keratinized surfaces and commonly affected sites include lateral and ventral tongue, buccal mucosa and soft palate. ${ }^{41}$ With radiation therapy, the damage is applied in several small daily doses over a period of weeks. ${ }^{39}$ Mucosal injury usually occur at cumulative radiation doses of about $15 \mathrm{~Gy} .{ }^{39}$ In radiation-induced oral mucositis, non-keratinized tissues are more often affected, and the clinical severity is directly proportional to the radiation dose. The lesions are specific to the tissues in the field of radiation. ${ }^{40}$

Prior to ulceration, a white discoloration of the mucosa can be seen as a result of a transient hyper-keratinization of the epithelium. ${ }^{42}$ This is followed by thinning of the epithelium due to loss of renewal capacity caused by the indirect damage to epithelial stem cell. ${ }^{39}$ This results in erythema from increased vascularity. The loss of mucosal integrity then manifests as painful ulcers and confluent pseudomembranous reactions with severe necrosis that can result in treatment cessation due to excruciating pain, risk of infection and reduced quality of life. ${ }^{36,39}$ The pseudomembranous appearance of the mucosa is the result of fibrinous bacterial exudate. ${ }^{39}$ Mucositis is a selflimiting condition where the ulcers resolve spontaneously within two to three weeks following the completion of treatment. ${ }^{39,43}$

Scoring systems are used to document the degree of oral mucositis and to evaluate the effects of intervention measures. ${ }^{44}$ One of the most common grading system is the World Health Organization grading system. ${ }^{45}$ This score system assesses mucosal changes, symptoms, and functional impact on the patient, and classifies oral mucositis into five groups:
- Grade 0: No signs or symptoms

- Grade 1: Mild soreness or painless ulcers with edema or erythema

- Grade 2: Pain, erythema, ulcers, ability to eat solids

- Grade 3: Pain, erythema, ulcers requires soft or liquid diet

- Grade 4: Severe ulcers with extensive erythema; patient cannot swallow food $^{40,44}$

The risk of oral mucositis and management of symptoms should be discussed with all patients prior to receiving cancer therapy with the importance of good oral hygiene highlighted. The recommended management of patients with oral mucositis includes:

- Eliminating infection and irritation and establishing effective oral hygiene practices

- Frequent use of mouth rinses (e.g. a teaspoon of salt and sodium bicarbonate in a tumbler of warm water to use as frequently as needed)

- Avoiding tobacco, alcohol and carbonated drinks

- Soft diet (this will require the input of a dietician) and

- Maintaining adequate hydration levels. ${ }^{27}$

The Multinational Association of Supportive Care in Cancer and International Society of Oral Oncology (MASCC/ISOO) have published evidence-based clinical practice guidelines for the management oral mucositis. ${ }^{46}$ The guidelines include options such as growth factors, anti-inflammatory agents, antimicrobials, coating agents, anesthetics and analgesics, laser and other 
light therapy, cryotherapy, and natural and other miscellaneous agents with their suggested use dependent on the type of cancer treatment received. ${ }^{46}$ For example, low-level laser therapy has been suggested to be used to control the intensity and pain of mucositis. ${ }^{47,48}$ Mixed medication mouthwashes consisting of topical coating, anesthetic, and possibly other agents have also been suggested as part of the supportive care but there is inadequate and/or conflicting evidence to support their use. $^{46}$ Based on clinical experience, topical anesthetic agents (viscous xylocaine) can be applied on oral ulcerations to control pain and to allow patients to eat and do oral hygiene; however, the effects are transient. ${ }^{49,50}$

\section{Oral infections}

Oral bacterial, fungal and viral infections are significant causes of morbidity amongst cancer patients. ${ }^{51}$ These may result from changes to the indigenous microflora due to cancer therapies, myelosuppression, impaired host defense mechanisms, salivary gland dysfunction and poor oral health and hygiene. ${ }^{51,52}$ In addition, exacerbation of dental caries, periodontal disease and odontogenic infections are also potential issues. ${ }^{52}$ Routine oral hygiene measures and regular dental examination and care should form part of a preventative regime. ${ }^{51}$

Fungal infections, such as oral candidiasis, are common in cancer patients. ${ }^{53,54}$ Chemotherapy, radiotherapy, salivary gland dysfunction and mucosal fragility provide an ideal environment for proliferation by candida species which can be managed by prescribing Nystatin 100,000 IU/mL four times/day for 7-14 days. ${ }^{53-55}$
Neutropenic patients are also at higher risk of developing viral infections with herpes simplex, one of the most common infections resulting in pain, discomfort, dehydration and malnutrition. ${ }^{56} \mathrm{~A}$ major oral complication is the spread of potentially life-threatening infection. Pharmacological management includes oral Acyclovir 400 mg three times/day for 10 days or longer and oral Valacyclovir 500-1000 mg twice/ day for 10 days or longer. ${ }^{56,57}$

\section{Dry mouth}

Xerostomia (a subjective feeling of dry mouth) and salivary gland hypofunction (chronic reduction of salivary output due to glandular changes) are both common complications of cancer therapy. Although the terms are often used interchangeably, they represent different manifestations that may or may not be related. ${ }^{58}$ Quantitative and qualitative salivary changes predispose these patients, especially those irradiated for head and neck cancer, to oral discomfort, taste disturbances, difficulty chewing, and impairment of swallowing and speaking. ${ }^{59}$ In addition, dry mouth can exacerbate caries risk. ${ }^{60}$ Saliva stimulants, such as chewing gum, have been recommended for symptomatic treatment. Saliva substitutes are also suggested, for example Biot ne ${ }^{\circledR}$ Oral Balance Moisturizing Gel. ${ }^{61,62}$

\section{Taste disturbances}

Hypogeusia (no taste) and dysgeusia (altered taste) are relatively common in cancer patients and may be the result of the cancer, its management or damage of cranial nerves. ${ }^{63,64}$ Management may include treatment of the underlying cause and dietary therapy. ${ }^{63}$ 
Late side effects

5. Radiation caries (Figure 4)
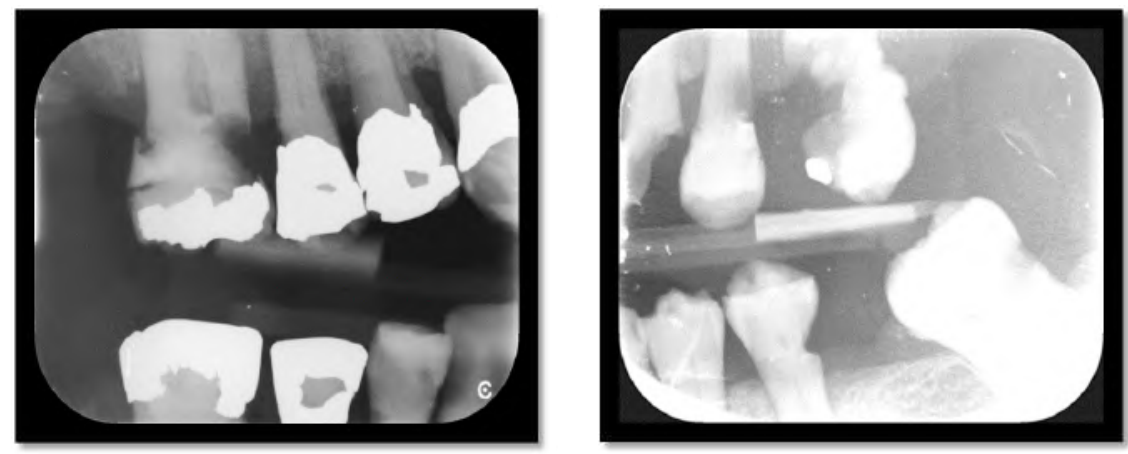

Figure 4. Bitewings radiographs showing evidence of caries in a patient exposed to radiation to head and neck

Source: by the authors

Radiation caries is mainly attributed to radiation-induced damage to the salivary glands and subsequent reduced saliva production; however, there may be other contributing factors. ${ }^{65}$ For example, weight loss can be an issue during cancer treatment resulting in patients being recommended to eat frequent small meals with emphasis on high caloric foods. Patients are also supplemented with liquids containing refined carbohydrates that predispose sugar adhesion to dental surfaces. ${ }^{66}$ Patients may find it difficult to brush between feeding due to the increased frequency of meals which may be further complicated by pain associated with mucositis causing increased plaque accumulation. Patients may also place more importance on other treatment rather than dental care which results in long delays between oral intake and oral hygiene. ${ }^{65,66}$ Furthermore, it has been demonstrated an increase in cariogenic oral bacteria, including Streptococcus and Lactobacillus species, in patients with head and neck cancer receiving radiation. ${ }^{67}$ This can lead to progressive destruction of tooth structure due to the acidogenic-aciduric properties of these microorganisms. ${ }^{68}$
During and after radiotherapy treatment, it is important to establish good oral health habits. Brushing 2-4 times daily with a soft-bristled toothbrush and a high fluoride content toothpaste such as Colgate ${ }^{\circledR}$ PreviDent $^{\circledR} 5000$ Plus. Flossing is also of paramount importance to oral hygiene once the mucosal status permits this. ${ }^{69,70}$ Custom carrier trays for application of fluoride are indicated. ${ }^{69}$ Antibacterial mouthwashes, such as chlorhexidine solutions $(0.12 \%-0.2 \%)$, can be used to control plaque accumulation. ${ }^{71}$ Sugar-free gums containing xylitol can be used to stimulate saliva with the aim of increasing buffering capacity and sugar clearance. $^{72}$

Frequent follow-up appointments are recommended after completion of radiotherapy. ${ }^{69}$ Caries removal and restorations should not be delayed. ${ }^{69}$ Restoration of these teeth may prove to be difficult due to the extent of caries and especially for lesions located cervically. ${ }^{69}$ Material selection can be also difficult due the challenging oral environment found in irradiated patients. ${ }^{69}$ The ideal dental material should have good adhesive properties, assist with prevention 
of secondary caries, and withstand the challenges of a dry and acidic oral environment. Fluoride-releasing materials (e.g. glass ionomer cements) have proven to be effective in the management of caries in irradiated patients although erosion of the material remains a concern. ${ }^{69,73}$

\section{Trismus}

Trismus refers to restricted mouth opening $(<35 \mathrm{~mm}$, measured between the central incisors) that may occur as a direct result of cancer invading the temporomandibular joint or masticatory muscles, or as a consequence of tissue fibrosis from radiotherapy. ${ }^{74,75}$ Quality of life may subsequently be affected by impairment of communication, oral hygiene and dental care. ${ }^{76}$ At risk patients should be informed and preventive measures such as exercise therapy, instigated. ${ }^{76}$ For example, use of wooden tongue depressors to improve both vertical and horizontal jaw motion. It should be initiated as soon as possible following radiation in at risk patients and consists of holding the depressors between the teeth for 30 seconds 6 to 10 times per day and gradually inserting a new tongue depressor in increments of approximately $2 \mathrm{~mm}$ to enhance opening. ${ }^{76,77}$

\section{Osteoradionecrosis. (Figure 5)}

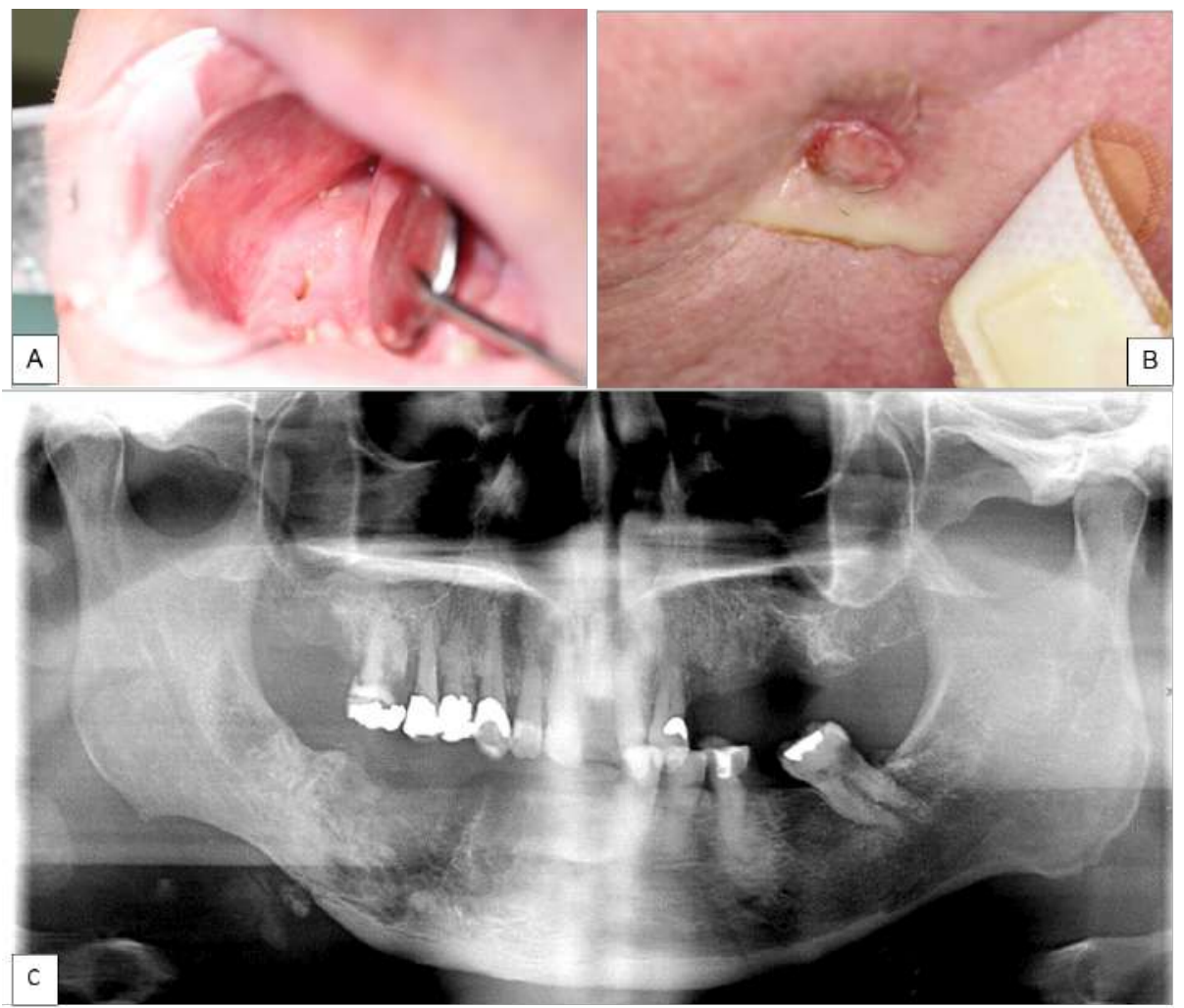

Figure 5. A. Intraoral imagen showing an area of exposed necrotic bone 5 months post extraction of teeth 44, 45, 46, and 47. B. Extraoral imagen showing a cutaneous sinus tract on the right side of the mandible. C. OPG showing evidence ORN of the mandible in the right posterior region with a pathological fracture. 
Radiotherapy to the orofacial structures places patients at higher risk of developing osteoradionecrosis (ORN), not to be confused with MRONJ. Prevalence rate ranges from $5 \%$ to $15 \% .{ }^{78}$ The incidence of ORN is relatively low $(5.5 \%)$ but management can prove difficult. ${ }^{79,80} \mathrm{ORN}$ is one of the most severe chronic side effects of radiotherapy, being more common in the mandible and is rare where radiation doses fall below 60 Gy..$^{81-83}$ The pathophysiology remains unclear but proposed to result from defective osteogenesis due to radiationinduced fibrosis. ${ }^{84}$ It has been also reported that radiation can lead to an imbalance between bone resorption and bone formation due to the damage of osteoblast and increased activity of osteoclasts. ${ }^{85}$ These changes appear to develop earlier than vascular alterations. ${ }^{86}$ The main clinical feature is an area of exposed bone following radiotherapy that may occur either after a traumatic event (e.g. dental extraction) or spontaneously in the absence of malignancy in the region. ${ }^{75}$

Prevention is paramount because its progression may lead to complications, including pathological fractures and local or systemic infection. ${ }^{87,88}$ Pre-treatment dental assessments include the removal of teeth with poor prognosis (non-restorable teeth with caries, severe periodontal disease, or with latent infections) prior to radiotherapy (preferably at least 3 weeks before to allow healing). ${ }^{27,88,89}$ Patients should be reviewed closely to ensure healing (gingival closure of extraction sites) and subsequently followed regularly (every 1-2 weeks) during radiotherapy. Thereafter, monthly reviews should be performed in the first six months to assist with oral rehabilitation, including treating any caries or new dental conditions, and monitoring of oral hygiene. ${ }^{88}$

If a dental extraction is required after head and neck radiotherapy, the patient should be referred to an oral surgeon. Treatment of ORN remains difficult and controversial but all suspected cases should be referred for specialist management. ${ }^{88,90}$ Adjunctive treatments that may be considered include conservative measures, sequestrectomy, hyperbaric oxygen therapy and PENTOCLO treatment (pentoxifylline combined with vitamin E). ${ }^{80,88,90}$

Table 1 presents a summary of oral complications of cancer treatment and management. 
Table 1: Oral complications of cancer treatment, clinical presentation and management ${ }^{12,51,69}$

\begin{tabular}{|c|c|c|}
\hline Oral manifestation & Clinical presentation & Management \\
\hline Oral mucositis & $\begin{array}{c}\text { Erythema of the mucosa } \\
\text { Patchy or confluent ulcerations, sometimes covered by } \\
\text { a pseudomembrane } \\
\text { Tissue necrosis } \\
\text { Bleeding with minor trauma }\end{array}$ & $\begin{array}{c}\text { Elimination of infection and irritation } \\
\text { Establish effective oral hygiene practices } \\
\text { Frequent use of mouth rinses } \\
\text { Advise patients to avoid tobacco, alcohol and carbonated drinks } \\
\text { Soft diet } \\
\text { Maintaining adequate hydration levels }\end{array}$ \\
\hline \multicolumn{3}{|l|}{ Oral infections } \\
\hline $\begin{array}{l}\text { - Bacterial e.g. } \\
\text { odontogenic deep } \\
\text { space infection }\end{array}$ & $\begin{array}{l}\text { Facial swelling } \\
\text { Pain } \\
\text { Fever }\end{array}$ & $\begin{array}{l}\text { In immunocompromised hosts: broad spectrum antimicrobial } \\
\text { should be prescribed e.g. cefotaxime } 2 \text { g IV q } 6 \text { hour }\end{array}$ \\
\hline $\begin{array}{l}\text { - Fungal e.g. } \\
\text { pseudomembranous } \\
\text { candidiasis }\end{array}$ & $\begin{array}{l}\text { Pseudomembranous patches } \\
\text { Mucosal erythema }\end{array}$ & Nystatin $100,000 \mathrm{IU} / \mathrm{mL}$ four times/day for 7-14 days \\
\hline $\begin{array}{l}\text { - Viral e.g. herpes } \\
\text { simplex virus }\end{array}$ & $\begin{array}{c}\text { Vesicles } \\
\text { Small crops of ulcers or more florid reaction } \\
\text { Cold sore }\end{array}$ & $\begin{array}{l}\text { Acyclovir } 400 \mathrm{mg} \text { three times/day for } 10 \text { days or longer } \\
\text { Oral Valacyclovir } 500-1000 \mathrm{mg} \text { twice/day for } 10 \text { days or longer }\end{array}$ \\
\hline $\begin{array}{l}\text { Salivary gland } \\
\text { dysfunction }\end{array}$ & $\begin{array}{c}\text { Xerostomia } \\
\text { Oral discomfort } \\
\text { Difficulty chewing and swallowing } \\
\text { Altered taste } \\
\text { Halitosis } \\
\text { Oral infection }\end{array}$ & $\begin{array}{c}\text { Symptomatic treatment } \\
\text { Saliva stimulants: chewing gum } \\
\text { Saliva substitutes: Biotène }{ }^{\circledR} \text { Oral Balance Moisturizing Gel }\end{array}$ \\
\hline Taste disturbances & Unpleasant taste of food & $\begin{array}{l}\text { Treatment of the underlying cause } \\
\text { Dietary therapy }\end{array}$ \\
\hline Radiation caries & $\begin{array}{c}\text { - Type } 1 \\
\text { Most common } \\
\text { Affects the cervical aspect of the teeth extending to } \\
\text { cementoenamel junction } \\
\text { Circumferential decay develops often resulting in } \\
\text { crown amputation } \\
- \text { Type } 2 \\
\text { Areas of demineralization on all dental surfaces } \\
\text { Generalized erosion } \\
\text { Worn out occlusal and incisal surfaces } \\
- \text { Type } 3 \\
\text { Least common pattern } \\
\text { Color changes in the dentin (Crown becomes dark } \\
\text { brown-black) } \\
\text { Occlusal and incisal wear }\end{array}$ & $\begin{array}{c}\text { Establish good oral health habits } \\
\text { Brushing 2-4 times daily with a soft-bristled toothbrush and a } \\
\text { high fluoride content toothpaste } \\
\text { Custom carrier trays for application of fluoride } \\
\text { Caries removal and teeth restorations should not be delayed }\end{array}$ \\
\hline Trismus & $\begin{array}{l}\text { Restricted mouth opening }(<35 \mathrm{~mm} \text {, measured } \\
\text { between the central incisors) }\end{array}$ & $\begin{array}{l}\text { Exercise therapy } \\
\text { Stretching the mouth using wooden tongue depressors }\end{array}$ \\
\hline Osteoradionecrosis & $\begin{array}{l}\text { Area of exposed bone following radiotherapy } \\
\text { Possible pain or secondary infection, } \\
\text { May progress to formation of a sequestrum, cutaneous } \\
\text { fistula and/or pathological fracture }\end{array}$ & $\begin{array}{l}\text { Management remains difficult } \\
\text { Refer patient to an oral surgeon }\end{array}$ \\
\hline
\end{tabular}

Source: by the authors 


\section{Treatment planning modifications}

General dental practitioners can play an important role in managing cancer patients in all three phases of multidisciplinary management: pre-treatment evaluation and preparation, during treatment and posttreatment. ${ }^{27}$ In doing so, dentists need to appreciate that there are often challenges faced beyond dental care. Therefore, collaboration with and/or referral to specialists with sufficient oral health and non-oral health training and experience, such as oral surgeons and stomatologists, is beneficial. $^{4,7}$ In addition, collaboration outside of traditional oral health physicians should also be considered.

\section{Pre-antineoplastic treatment evaluation and patient preparation}

As mentioned previously, the objectives of early intervention include identifying and eliminating sources of infection, identifying oral manifestations of the cancer and minimizing and treating oral sequelae that can arise as a result of antineoplastic therapy (Figure 6). ${ }^{27,63}$

\section{Pre-antineoplastic treatment evaluation and patient preparation}

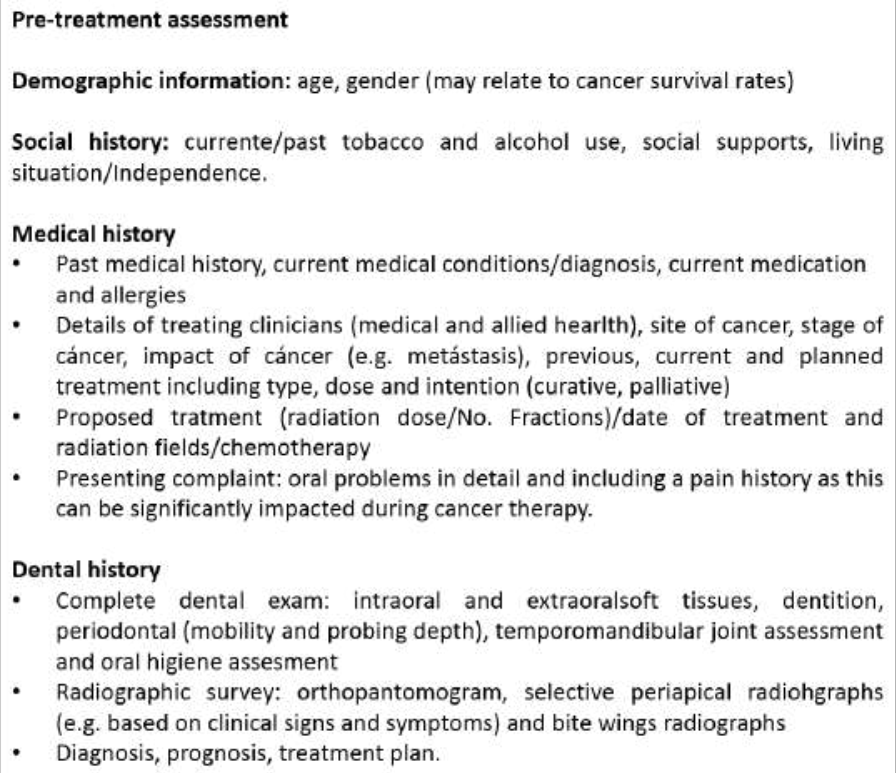

- Past medical history, current medical conditions/diagnosis, current medication and allergies

- Details of treating clinicians (medical and allied hearlth), site of cancer, stage of cáncer, impact of cáncer (e.g. metástasis), previous, current and planned treatment including type, dose and intention (curative, palliative)

- Proposed tratment (radiation dose/No. Fractions)/date of treatment and radiation fields/chemotherapy

- Presenting complaint: oral problems in detail and including a pain history as this can be significantly impacted during cancer therapy.

Dental history

- Complete dental exam: intraoral and extraoralsoft tissues, dentition, periodontal (mobility and probing depth), temporomandibular joint assessment and oral higiene assesment

- Radiographic survey: orthopantomogram, selective periapical radiohgraphs (e.g. based on clinical signs and symptoms) and bite wings radiographs

- Diagnosis, prognosis, treatment plan.

Pre-treatment dental interventions

- Oral higiene instructions

- Prophylaxis and supragingival scaling

- Treatment of acute dental problems

- Extrations (high risk)

- Unrestorable teeth

- Active periapical disease - symptomatic teeth

- Moderate to advanced periodontal disease

- Elimination of Sharp surfaces on teeth

Improving ill-fitting dentures

Subgingival scaling and root planning (high risk)

Postpone elective treatment

*High risk treatment

Evaluate haematological índices and consider the need

for antibiotic prophylaxis:

2 weeks prior chemotherapy and radiotherapy

Figure 6. Pre-antineoplastic treatment evaluation and patient preparation

Source: by the authors

A comprehensive dental examination should include a record of the dentition and assessment of dentures. ${ }^{91}$ A panoramic radiograph plus selective intraoral films should be used to determine the presence of periapical abnormalities, dental caries and 
periodontal disease. ${ }^{92}$ Full mouth periodontal charting at baseline is also recommended where possible. This should, however, be avoided in patients with platelets counts of less than $\geq 20,000$ cells/ $\mu \mathrm{L}^{27,93,94}$ or when neutrophil counts are less than 1,500 cell $/ \mathrm{mm}^{3} .4,95$ At this stage, it is important to promote meticulous oral hygiene. ${ }^{93}$ Commonly used preventive measures are described in Table 2..$^{27,96}$

Table 2. Preventive measures to maintain oral health in patients with cancer

- Brush teeth twice daily with high concentrated fluoride toothpaste, for example Colgate ${ }^{\circledR}$ PreviDent $^{\circledR} 5000$ Plus

- An ultra-soft or a soft toothbrush is preferred but brushing with sponge brushes is an option in patients with friable mucosa

- Use products with remineralization properties, for example MI Paste Family - GC America

- Chlorhexidine gluconate $0.2 \%$ mouth rinses may be recommended (preferably alcohol-free)

Source: by the authors

Communication with the multidisciplinary cancer care team is essential to discuss the patient's medical and hematological status. ${ }^{71}$ Ideally, dental treatment should be tailored to the patient's needs involving a shared care approach between the dental oncology service and the primary care dentist. ${ }^{71}$ In some circumstances, patients may receive all treatment from their general dental practitioner. ${ }^{5}$ Dental treatment should be directed towards acute dental problems, foci of infection, non-restorable teeth, sharp surfaces on teeth and ill-fitting dentures with the frequency of visits determined by each individual's needs. . $^{27,71,97}$

Dental procedures in the pre-treatment phase should also include oral hygiene instructions, simple restorations for adequacy of the oral environment, prophylaxis and supragingival scaling. ${ }^{4}$ Elective treatment should be postponed until the patient is medically stable without marked neutropenia or thrombocytopenia. ${ }^{98}$ The need for antibiotic prophylaxis should also be discussed with the patient's medical (and allied health) team. ${ }^{4}$

Scaling, extractions, and endodontic treatment, including retreatment, all carry potential risks in this cohort and their need should be discussed within the multidisciplinary team. ${ }^{4}$ Dental extractions and periodontal treatment should be completed at least 14 days before cancer treatment commences to allow adequate healing. ${ }^{51}$ In certain circumstances, delays may be necessary (e.g. where tooth extractions are required prior to head and neck radiotherapy). ${ }^{99}$ Likewise, patients with hematological cancer require urgent elimination of sources of infection to prevent risk of febrile neutropenia. ${ }^{4}$

\section{Oral health care during treatment. (Figure 7)}

Dentists should regularly monitor the oral cavity throughout cancer treatment to ensure optimal oral health and manage any side effects of antineoplastic therapy. ${ }^{4}$ Depending on the cancer therapy planned, it may be possible to complete dental treatment between chemotherapy cycles. ${ }^{4}$ If invasive dental treatment is required, evaluate hematological indices and the need for antibiotic prophylaxis in conjunction with the patient's medical team (Figure 4). ${ }^{4}$ A patient's blood cells will reach their lowest number (nadir) 7 to 14 days after initiation of chemotherapy. Surgical dental procedures can be performed after the neutrophil count has begun to rise from the nadir. ${ }^{12}$ 


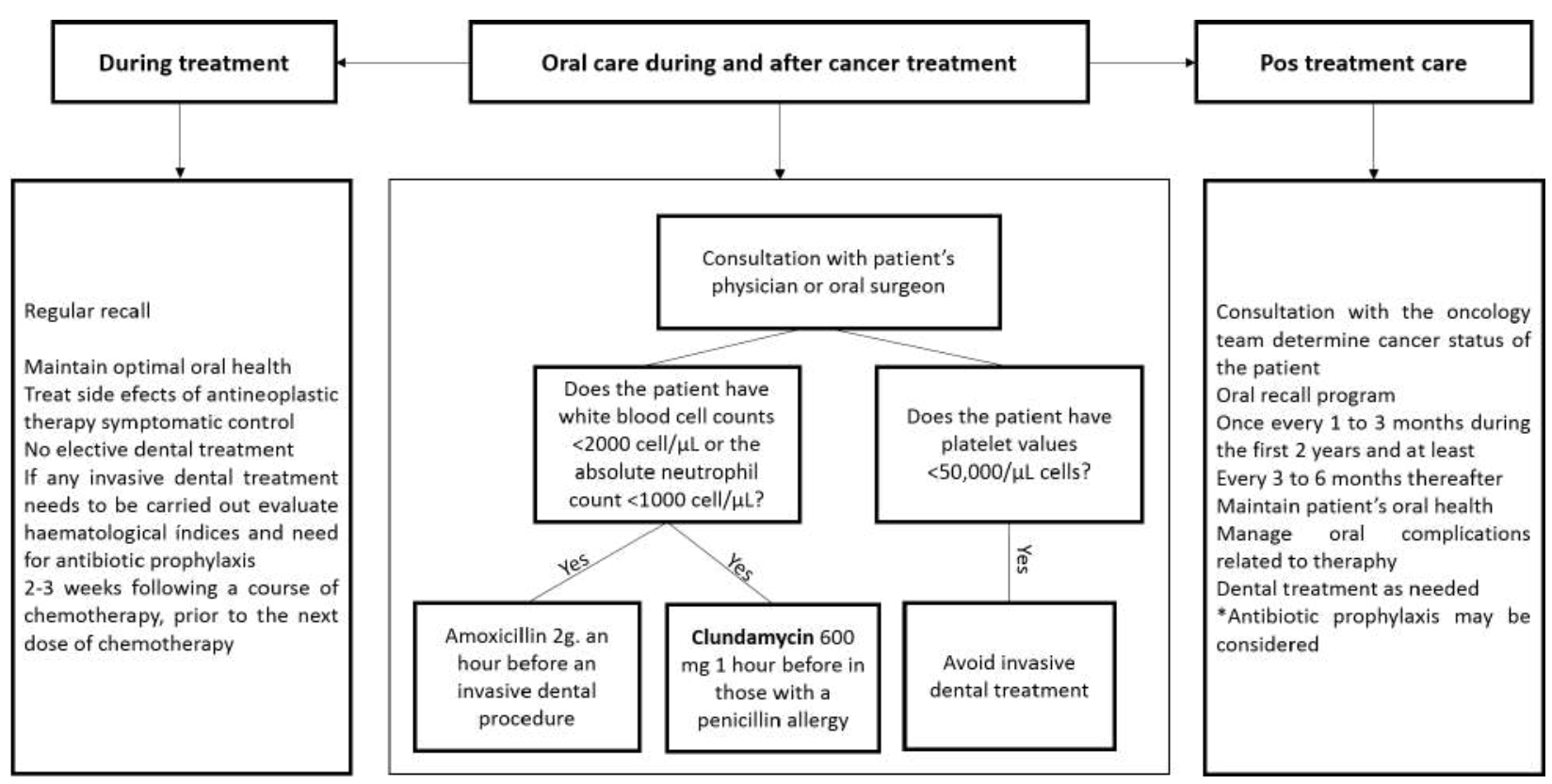

Figure 7. Oral management during cancer treatment and post neoplastic treatment

Source: by the authors

\section{Post treatment care}

Consultation with the oncology team is also recommended post-cancer therapy (Figure 7). ${ }^{27}$ Patients should be placed on an oral recall program (every 1-3 months during the first two years, at least 3-6 monthly thereafter). ${ }^{27}$ The aim is to maintain oral health and detect and manage oral complications related to therapy or cancer reoccurrence. All dental procedures can be performed post-chemotherapy as long as hematological indices are normal. ${ }^{4}$ Regarding radiotherapy to head and neck, dentists should always remember that patients are at lifetime risk of osteoradionecrosis of the jaw. ${ }^{83}$

\section{CONCLUSION}

To safely provide dental treatment, dentists should be aware of the pathophysiology of cancer and the spectrum of complications associated with the disease and therapies.
Dental management may be preventive, curative or palliative. The dentist's role within the multidisciplinary team is to ensure coordination of dental care and prioritize oral care appropriate to the patient's medical needs and within their scope of clinical competency.

\section{CONFLICT OF INTERESTS}

The authors declare that they have no conflict of interest.

\section{CORRESPONDING AUTHOR}

Claudia Patricia Lopez Silva

University of Melbourne. Melbourne Dental School

(+61) 393411529

closi21@hotmail.com

720 Swanston Street, Victoria 3053

Melbourne. Australia 


\section{REFERENCES}

1. Hancock PJ, Epstein JB, Sadler GR. Oral and dental management related to radiation therapy for head and neck cancer. Journal Can Dento Assoc. 2003; 69(9): 585-90.

2. Levi LE, Lalla RV. Dental treatment planning for the patient with oral cancer. Dent Clin North Am. 2018; 62(1): 121-30. DOI: https://doi.org/10.1016/j.cden.2017.08.009

3. Harrison LB, Sessions RB, Kies MS. Head and neck cancer: a multidisciplinary approach. 4th. Philadelphia: Wolters Kluwer Health/Lippincott Williams \& Wilkins; 2014 Fourth Edition; 2014.

4. Zimmermann C, Meurer MI, Grando LJ, Gonzaga Del Moral J, da Silva Rath IB, Schaefer Tavares S. Dental treatment in patients with leukemia. J Oncol. 2015; 2015: 571739.

5. G mez GJ ,Camacho RVL, Torres JEB, G mez SMB, Izate DPC, Ross PAC et al. Alterations found in the mouth of patients treated with head and neck radiotherapy. Medellin, Colombia. Rev Odont Mex. 2017; 21(2): e86-96. DOI: https://doi.org/10.1016/j.rodmex.2017.05.012

6. Dental Board of Australia. List of specialties, 2016 [Internet]. Available in https://www.dentalboard.gov.au/ Registration/Specialist-Registration.aspx

7. Epstein JB, G neri P, Barasch A. Appropriate and necessary oral care for people with cancer: guidance to obtain the right oral and dental care at the right time. Support Care Cancer. 2014; 22(7): 1981-8. DOI: https://doi.org/10.1007/s00520-014-2228-x

8. Colombia. Minsiterio de Educaci n. Observatorio laboral para la educaci n: programas de carrera [Internet]. Available in: http://bi.mineducacion.gov.co:8380/eportal/web/men-observatorio-laboral

9. Universidad de Buenos Aires. Carrera de especializaci $\mathrm{n}$ en odontolog a integral para personas con riesgo $\mathrm{m}$ dico y discapacidad [Internet]. Available in: http://www.uba.ar/posgrados/noticia.php?id=254.

10. Epstein JB, Parker IR, Epstein MS, Stevenson-Moore P. Cancer-related oral health care services and resources: a survey of oral and dental care in Canadian cancer centres. J Can Assoc. 2004; 70(5): 302-4

11. Brennan M, Lockhart P. Oral assessment. En: Davies AN, Epstein JB, editors. Oral complications of cancer and its management. Oxford University Press; 2010. p. 21-4.

12. Little JW. Little and Falace's dental management of the medically compromised patient. 8th ed. London: Mosby; 2012.

13. da Silva Santos PS, Fontes A, de Andrade F, de Sousa SC. Gingival leukemic infiltration as the first manifestation of acute myeloid leukemia. Otolaryngol-Head Neck Surg. 2010; 143(3): 465-6. DOI: https:// doi.org/10.1016/j.otohns.2010.04.010

14. Glaspy J. Disorders of blood cell production in clinical oncology. In: Niederhuber JE, Armitage JO, Doroshow JH, Kastan MB, Tepper JE, editors. Abeloff's clinical oncology. 5th ed. Philadelphia: Saunders Elsevier, 2013. p. 532-41.

15. Oral complications of chemotherapy and head/neck radiation (pdq®): health professional version. PDQ Cancer Information Summaries; 2002.

16. Nizarali N, Rafique S. Special care dentistry: part 3. Dental management of patients with medical conditions causing acquired bleeding disorders. Dent Update. 2013; 40(10): 805-8

17. Falanga A, Marchetti $M$, Vignoli A. Coagulation and cancer: biological and clinical aspects. J Thromb Haemost. 2013; 11(2): 223-33. DOI: https://doi.org/10.1111/jth.12075

18. Cipta AM, Pietras CJ, Weiss TE, Strouse TB. Cancer-related pain management in clinical oncology. J Community Support Oncol. 2015; 13(10): 347-55. DOI: https://doi.org/10.12788/jcso.0173 
19. Epstein JB, Wilkie DJ, Kim Y-O, Fischer DJ, Villines D. Neuropathic and nociceptive pain in head and neck cancer patients receiving radiation therapy. Head Neck Oncol. 2009; 14: 1-26. DOI: https://doi. org/10.1186/1758-3284-1-26

20. Oliveira KG, von Zeidler SV, Podest JR, Sena A, Souza ED, Lenzi J et al. Influence of pain severity on the quality of life in patients with head and neck cancer before antineoplastic therapy. BMC Cancer. 2014; 39.

21. Epstein JB, Thariat J, Bensadoun R-J, Barasch A, Murphy BA, Kolnick L et al. Oral complications of cancer and cancer therapy: from cancer treatment to survivorship. CA Cancer J Clin. 2012; 62(6): 400-22. DOI: https://doi.org/10.3322/caac.21157

22. Grossman SA, Nesbit S. Cancer-related pain. En: Niederhuber JE, Armitage JO, Doroshow JH, Kastan MB, Tepper JE, editors. Abeloff's clinical oncology. 5th ed. Philadelphia: Saunders Elsevier, 2013. p. 608-19.

23. Hainsworth JD. Nausea and vomiting. En: Niederhuber JE, Armitage JO, Doroshow JH, Kastan MB, Tepper JE, editors. Abeloff's clinical oncology. 5th ed. Philadelphia: Saunders Elsevier, 2013. p. 626-34.

24. Brell JM, Jones LW. Fatigue. En: Niederhuber JE, Armitage JO, Doroshow JH, Kastan MB, Tepper JE, editors. Abeloff's clinical oncology. 5th ed. Philadelphia: Saunders Elsevier, 2013. p. 676-81.

25. Mason H, DeRubeis MB, Burke N, Shannon M, Karsies D, Wolf G et al. Symptom management during and after treatment with concurrent chemoradiotherapy for oropharyngeal cancer: a review of the literature and areas for future research. World J Clin Oncol. 2016; 7(2): 220-6. DOI: https://dx.doi.org/10.5306\%2Fwjco.v7.i2.220

26. Treatment-related nausea and vomiting $\left(\mathrm{PDQ}{ }^{\circledR}\right)$ : health professional version. PDQ Cancer Information Summaries. 2002.

27. Little JW, Miller C, Rhodus N, Falace DA. Little and Falace's dental management of the medically compromised patient. St. Louis: Mosby; 2012.

28. Taichman S, Gomez G, Rohr Inglehart M. Oral Health Care during Chemotherapy. RDH. 2013; 33(4):67-74.

29. Henry L, Loader G. Nutrition support A2. En: Treleaven J, Barrett AJ, editor. Hematopoietic stem cell transplantation in clinical practice. Edinburgh: Churchill Livingstone; 2009. p. 343-54.

30. Zheng H, Kobrinsky B, Katz S, Speyer JL. Cardiac effects of cancer therapy. In: Niederhuber JE, Armitage JO, Doroshow JH, Kastan MB, Tepper JE, Abeloff MD, editors. Abeloff's clinical oncology. 5th ed. Philadelphia, Pennsylvania: Saunders Elsevier; 2013. p. 858-73.

31. Jowett NI, Cabot LB. Patients with cardiac disease: considerations for the dental practitioner. Br Dent J. 2000; 189(6): 297-302. DOI: https://doi.org/10.1038/sj.bdj.4800750

32. Malamed SF. Physical and psychological evaluation. In: Sedation. 5th ed. Saint Louis: Mosby; 2010. p. 23-62.

33. Coleman RE, Holen I. Bone Metastases In: Niederhuber JE, Armitage JO, Doroshow JH, Kastan MB, Tepper JE, Abeloff MD, editors. Abeloff's clinical oncology. 5th ed. Philadelphia, Pennsylvania: Saunders Elsevier; 2013. p. 739-63.

34. Ruggiero SL, Dodson TB, Fantasia J, Goodday R, Aghaloo T, Mehrotra B et al. American association of oral and maxillofacial surgeons position paper on medication-related osteonecrosis of the jaw--2014 update. J Oral \& Maxillofac Surg. 2014; 72(10): 1938-56. DOI: https://doi.org/10.1016/j.joms.2014.04.031

35. Sanders K, Sim I-W, Sanders KM, Ebeling PR, Borromeo GL, Seymour JF. Declining incidence of medicationrelated osteonecrosis of the jaw in patients with cancer. J Clin Endocrinol Metab. 2015; 100(10): 3887-93. DOI: https://doi.org/10.1210/jc.2015-1794

36. Alvarado Y, Bellm LA, Giles FJ. Oral mucositis: time for more studies. Hematology. 2002; 7(5): 281-9. DOI: https://doi.org/10.1080/1024533021000037216 
37. de Oliveira Lula EC, de Oliveira Lula CE, Alves CMC, Lopes FF, Pereira ALA. Chemotherapy-induced oral complications in leukemic patients. Int J Pediatr Otorhinolaryngol. 2007; 71(11): 1681-5. DOI: https://doi. org/10.1016/j.ijporl.2007.07.006

38. Barasch A, Peterson DE. Risk factors for ulcerative oral mucositis in cancer patients: unanswered questions. Oral Oncol. 2003; 39(2): 91-100

39. Sonis ST. A biological approach to mucositis. J Support Oncol. 2004; 2(1): 21-32.

40. Lalla RV, Sonis ST, Peterson DE. Management of oral mucositis in patients with cancer. Dent Clin North Am. 2008; 52(1): 61-viii. DOI: https://dx.doi.org/10.1016\%2Fj.cden.2007.10.002

41. Lalla RV, Peterson DE. Oral mucositis. Dent Clin North Am. 2005; 49(1): 167-84. DOI: https://doi. org/10.1016/j.cden.2004.07.009

42. Redding SW. Cancer therapy-related oral mucositis. J Dent Educ. 2005; 69(8): 919-29.

43. Sonis ST. Pathobiology of oral mucositis: novel insights and opportunities. J Support Oncol. 2007; 5(9): 3-11.

44. Naidu MUR, Ramana GV, Rani PU, Mohan IK, Suman A, Roy P. Chemotherapy-induced and/or radiation therapy-induced oral mucositis-complicating the treatment of cancer. Neoplasia. 2004; 6(5): 423-31. DOI: https://dx.doi.org/10.1593\%2Fneo.04169

45. Sroussi HY, Epstein JB, Bensadoun R-J, Saunders DP, Lalla RV, Migliorati CA et al. Common oral complications of head and neck cancer radiation therapy: mucositis, infections, saliva change, fibrosis, sensory dysfunctions, dental caries, periodontal disease, and osteoradionecrosis. Cancer Med. 2017; 6(12): 2918-31. DOI: https://doi.org/10.1002/cam4.1221

46. Lalla RV, Bowen J, Barasch A, Elting L, Epstein J, Keefe DM et al.. MASCC/ISOO Clinical practice guidelines for the management of mucositis secondary to cancer therapy. Cancer. 2014; 120(10): 1453-61. DOI: https://doi.org/10.1002/cncr.28592

47. Migliorati C, Hewson I, Lalla RV, Antunes HS, Estilo CL, Hodgson B et al. Systematic review of laser and other light therapy for the management of oral mucositis in cancer patients. Support Care Cancer. 2013; 21(1): 333-41. DOI: https://doi.org/10.1007/s00520-012-1605-6

48. Carvalho PAG, Jaguar GC, Pellizzon AC, Prado JD, Lopes RN, Alves FA. Evaluation of low-level laser therapy in the prevention and treatment of radiation-induced mucositis: a double-blind randomized study in head and neck cancer patients. Oral Oncol. 2011; 47(12): 1176-81. DOI: https://doi.org/10.1016/j. oraloncology.2011.08.021

49. Saunders DP, Epstein JB, Elad S, Allemano J, Bossi P, van de Wetering MD et al. Systematic review of antimicrobials, mucosal coating agents, anesthetics, and analgesics for the management of oral mucositis in cancer patients. Support Care Cancer. 2013; 21(11): 3191-207. DOI: https://doi.org/10.1007/s00520013-1871-y

50. Epstein JB, Thariat J, Bensadoun R-J, Barasch A, Murphy BA, Kolnick L et al. Oral complications of cancer and cancer therapy: from cancer treatment to survivorship. 2012; 62(6): 400-22. DOI: https://doi. org/10.3322/caac. 21157

51. Davies A, Epstein J. Oral complications of cancer and its management. Oxford: Oxford University Press; 2010.

52. Ruby J, Barbeau J. The buccale puzzle: the symbiotic nature of endogenous infections of the oral cavity. Can J of Infect Dis. 2002; 13(1): 34-41.

53. Samaranayake L, Sitheeque M. Oral fungal infections. In: Davies A, Epstein J, editors. Oral Complications of cancer and its management. Oxford: Oxford University Press; 2010. p. 171-83. 
54. Ramla S, Sharma V, Patel M. Influence of cancer treatment on the Candida albicans isolated from the oral cavities of cancer patients. Support Care Cancer. 2016; 24(6): 2429-36. DOI: https://doi.org/10.1007/ s00520-015-3035-8

55. Pappas PG, Kauffman CA, Andes DR, Clancy CJ, Marr KA, Ostrosky-Zeichner L et al. Clinical practice guideline for the management of candidiasis: 2016 update by the infectious diseases society of america. Clin Infect Dis. 2016; 62(4): e1-e50. DOI: https://doi.org/10.1093/cid/civ933

56. Elad S, Zadik Y, Hewson I, Hovan A, Correa ME, Logan R et al. A systematic review of viral infections associated with oral involvement in cancer patients: a spotlight on Herpesviridea. Support Care Cancer. 2010; 18(8): 993-1006. DOI: https://doi.org/10.1007/s00520-010-0900-3

57. Lerman MA, Laudenbach J, Marty FM, Baden LR, Treister NS. Management of oral infections in cancer patients. Dent Clin North Am. 2008; 52(1): 129-53. DOI: https://doi.org/10.1016/j.cden.2007.10.006

58. Thomson WM, Chalmers JM, Spencer AJ, Ketabi M. The occurrence of xerostomia and salivary gland hypofunction in a population-based sample of older South Australians. Spec Care Dentist. 1999; 19(1): 20-3

59. Dirix $\mathrm{P}$, Nuyts $\mathrm{S}$, Vander Poorten $\mathrm{V}$, Delaere $\mathrm{P}$, Bogaert $\mathrm{W}$. The influence of xerostomia after radiotherapy on quality of life: results of a questionnaire in head and neck cancer. Support Care Cancer. 2008; 16(2): 171-9. DOI: https://doi.org/10.1007/s00520-007-0300-5

60. Vissink A, Mitchell JB, Baum BJ, Limesand KH, Jensen SB, Fox PC et al. Clinical management of salivary gland hypofunction and xerostomia in head-and-neck cancer patients: successes and barriers. Int J Radiat Oncol Biol Phys. 2010; 78(4): 983-91. DOI: https://dx.doi.org/10.1016\%2Fj.ijrobp.2010.06.052

61. Davies A. Salivary gland dysfunction. In: Davies A, Epstein J, editors. Oral complications of cancer and its management. Oxford: Oxford University Press; 2010.

62. J Patricio UB, Felipe FC. Manejo actual de la xerostom a. Rev Otorrinolaringol Cir Cabeza Cuello. 2016; 76: $243-48$

63. Ripamonti C, Fulfaro F. Taste disturbances. In: Davies A, Epstein J, editors. Oral complications of cancer and its management. Oxford: Oxford University Press; 2010.

64. Jensen SB, Mouridsen HT, Bergmann OJ, Reibel J, Br nner N, Nauntofte B. Oral mucosal lesions, microbial changes, and taste disturbances induced by adjuvant chemotherapy in breast cancer patients. Oral Surg Oral Med Oral Pathol Oral Radiol Endod. 2008; 106(2): 217-26. DOI: https://doi.org/10.1016/j. tripleo.2008.04.003

65. Deng J, Jackson L, Epstein JB, Migliorati CA, Murphy BA. Dental demineralization and caries in patients with head and neck cancer. Oral Oncol. 2015; 51(9): 824-31. DOI: https://doi.org/10.1016/j. oraloncology.2015.06.009

66. McCaul LK. Oral and dental management for head and neck cancer patients treated by chemotherapy and radiotherapy. Dental Update. 2012; 39(2): 135-40. DOI: https://doi.org/10.12968/denu.2012.39.2.135

67. Lim H-S, Chung K-Y, Kim A-O, Kim M-R, Kim Y-S, Kang M-S et al. Cariogenic activity in saliva of Korean head and neck cancer patients. Int J Oral Biol. 2014; 39(2): 57-63. DOI: https://doi.org/10.11620/ IJOB.2014.39.2.057

68. Gonçalves LMN, Palma-Dibb RG, Paula-Silva FWG, de Oliveira HF, Nelson-Filho P, da Silva LAB et al. Radiation therapy alters microhardness and microstructure of enamel and dentin of permanent human teeth. J Dent. 2014; 42(8): 986-92. DOI: https://doi.org/10.1016/j.jdent.2014.05.011

69. Gupta N, Pal M, Rawat S, Grewal M, Garg H, Chauhan D et al. Radiation-induced dental caries, prevention and treatment - a systematic review. Natl J Maxillofac Surg. 2015; 6(2): 160-6. DOI: https://doi. org/10.4103/0975-5950.183870 
70. Kielbassa AM, Hinkelbein W, Hellwig E, Meyer-L ckel H. Radiation-related damage to dentition. Lancet Oncol. 2006; 7(4): 326-35. DOI: https://doi.org/10.1016/S1470-2045(06)70658-1

71. Barclay SC, Turani D. Current practice in dental oncology in the UK. Dent Update. 2010; 37(8): 555-8. DOI: https://doi.org/10.12968/denu.2010.37.8.555

72. Edgar WM, Higham SM, Manning RH. Saliva stimulation and caries prevention. Adv Dent Res. 1994; 8(2): 239-45. DOI: https://doi.org/10.1177/08959374940080021701

73. McComb D, Erickson RL, Maxymiw WG, Wood RE. A clinical comparison of glass ionomer, resin-modified glass ionomer and resin composite restorations in the treatment of cervical caries in xerostomic head and neck radiation patients. Oper Dent. 2002; 27(5): 430-7

74. Ichimura K, Tanaka T. Trismus in patients with malignant tumours in the head and neck. J Laryngol Otol. 1993; 107(11): 1017-20. DOI: https://doi.org/10.1017/s0022215100125149

75. Thorn JJ, Hansen HS, Specht L, Bastholt L. Osteoradionecrosis of the jaws: clinical characteristics and relation to the field of irradiation. J Oral Maxillofac Surg. 2000; 58(10): 1088-93. DOI: https://doi. org/10.1053/joms.2000.9562

76. Dijkstra P, Roodenburg J. Trismus. In: Davies A, Epstein J, editors. Oral complications of cancer and its management. Oxford: Oxford University Press; 2010. p. 99-116.

77. Buchbinder D, Currivan RB, Kaplan AJ, Urken ML. Mobilization regimens for the prevention of jaw hypomobility in the radiated patient: a comparison of three techniques. J Oral Maxillofac Surg.1993; 51(8): 863-7. DOI: https://doi.org/10.1016/s0278-2391(10)80104-1

78. Chronopoulos A, Zarra T, Ehrenfeld M, Otto S. Osteoradionecrosis of the jaws: definition, epidemiology, staging and clinical and radiological findings. A concise review. Int Dent J. 2018; 68(1): 22-30. DOI: https://doi.org/10.1111/idj.12318

79. Moon DH, Wang K, Marks LB, Chera BS, Moon SH, Weissler MC et al. Incidence of, and risk factors for, mandibular osteoradionecrosis in patients with oral cavity and oropharynx cancers. Oral Oncol. 2017: 72; 98-103. DOI: https://doi.org/10.1016/j.oraloncology.2017.07.014

80. Delanian S, Chatel C, Porcher R, Depondt J, Lefaix J-L. Complete restoration of refractory mandibular osteoradionecrosis by prolonged treatment with a pentoxifylline-tocopherol-clodronate combination (PENTOCLO): a phase II trial. Int J Radiat Oncol Biol Phys. 2011; 80(3): 832-9. DOI: https://doi. org/10.1016/j.ijrobp.2010.03.029

81. Schwartz HC, Kagan AR. Osteoradionecrosis of the mandible: scientific basis for clinical staging. Am J Clin Oncol. 2002; 25(2): 168-71.

82. Peterson DE, Doerr W, Hovan A, Pinto A, Saunders D, Elting LS, et al. Osteoradionecrosis in cancer patients: the evidence base for treatment- dependent frequency, current management strategies, and future studies. Support Care Cancer. 2010; 18(8): 1089-89. DOI: https://doi.org/10.1007/s00520-0100898-6

83. Kuhnt T, Stang A, Wienke A, Vordermark D, Schweyen R, Hey J. Potential risk factors for jaw osteoradionecrosis after radiotherapy for head and neck cancer. Radiat Oncol. 2016; 11: 101. DOI: https://dx.doi.org/10.1186\%2Fs13014-016-0679-6

84. Delanian S, Lefaix JL. Radion crose de l'os mature: connaissance physiopathologique $r$ cente motrice $\mathrm{d}^{\prime}$ une th rapeutique $\mathrm{m}$ dicale innovante $=$ mature bone necrosis: from recent pathophysiological aspect to a new therapeutic action. Cancer Radiother. 2002; 6(1): 1-9.

85. Szczepkowska A, Milner P, Janas A. Autofluorescence image of post-radiation maxillary bone osteonecrosis in a 64-year-old patient - case report. 2016; 10(1):69-72. DOI: https://doi.org/10.5604/18982395.1208194 
86. Jacobson AS, Buchbinder D, Hu K, Urken ML. Paradigm shifts in the management of osteoradionecrosis of the mandible. Oral Oncol. 2010; 46(11): 795-801. DOI: https://doi.org/10.1016/j.oraloncology.2010.08.007

87. Chronopoulos A, Zarra T, Ehrenfeld M, Otto S. Osteoradionecrosis of the jaws: definition, epidemiology, staging and clinical and radiological findings: a concise review. Int Dent J. 2018; 68(1): 22-30. DOI: https:// doi.org/10.1111/idj.12318

88. Nadella KR, Kodali RM, Guttikonda LK, Jonnalagadda A. Osteoradionecrosis of the jaws: clinico-therapeutic management. A literature review and update. J Maxillofac Oral Surg. 2015; 14(4): 891-901. DOI: https:// doi.org/10.1007/s12663-015-0762-9

89. Sulaiman F, Huryn J, Zlotolow I. Dental extractions in the irradiated head and neck patient: a retrospective analysis of memorial sloan-kettering cancer center protocols, criteria, and end results. J Oral Maxillofac Surg. 2003; 61(10): 1123-31. DOI: https://doi.org/10.1016/S0278-2391(03)00669-4

90. Lyons A, Osher J, Warner E, Kumar R, Brennan PA. Osteoradionecrosis-a review of current concepts in defining the extent of the disease and a new classification proposal. Br J Oral Maxillofac Surg. 2014; 52(5): 392-5. DOI: https://doi.org/10.1016/j.bjoms.2014.02.017

91. Schiødt M, Hermund NU. Management of oral disease prior to radiation therapy. Support Care Cancer. 2002; 10(1): 40-3.

92. Hancock PJ, Epstein JB, Sadler GR. Oral and dental management related to radiation therapy for head and neck cancer. J Can Dent Assoc. 2003; 69(9): 585-90

93. Vozza I, Caldarazzo V, Polimeni A, Ottolenghi L. Periodontal disease and cancer patients undergoing chemotherapy. Int Dent J. 2015; 65(1): 45-8. DOI: https://doi.org/10.1111/idj.12133

94. Bansal N, Jindal M, Gupta N, Shukla P. Clinical guidelines for periodontal management of idiopathic thrombocytopenic purpura: current considerations. Int J Oral Health Sci. 2017; 7(1): 30-4. DOI: https:// doi.org/10.4103/ijohs.ijohs_7_17

95. Sandra Olivia K, Yuniarti S, Sri Lelyati CM. Gingival enlargement as oral manifestation in acute myeloid leukemia patient. Madj Persat Dokt Gigi Indones. 2017. 50(3); 154-9. DOI: http://dx.doi.org/10.20473/j. djmkg.v50.i3.p154-159

96. National Institute of Dental and Craniofacial Research, National Cancer Institute, National Institute of Nursing Research, Centers for Disease Control and Prevention, U.S. Department of Health and Human Services. Oral complications of cancer treatment: what the dental team can do. Bethesda: Dental Team; [2009].

97. Stevenson-Moore P, Saunders D, Epstein J. Pretreatment screening and management. In: Davies A, Epstein J, editors. Oral Complications of Cancer and its management. Oxford: Oxford University Press; 2010.

98. American Academy of Pediatric Dentistry. Guideline on dental management of pediatric patients receiving chemotherapy, hematopoietic cell transplantation, and/or radiation. Pediatr Dent. 2013; 35(5): e185-93.

99. Devi S, Singh N. Dental care during and after radiotherapy in head and neck cancer. Natl J Maxillofac Surg. 2014; 5(2): 117-25. DOI: https://dx.doi.org/10.4103\%2F0975-5950.154812 